DRACH Oksana, Doctor of Sciences (History), Professor of the Department of History of Ukraine, Bohdan Khmelnytsky National University of Cherkasy,

e-mail: drach_oksana@ukr.net

\title{
EDUCATION AND SCHOOLING IN BYZANTIUM: PUBLIC EXPECTATIONS AND DI- DACTIC TASKS
}

Abstract. Introduction. An important paradigm for formation of the civilizational identity of the ancient Ukraine-Rus' was the accepting Christianity in the Byzantine (Eastern) Rite. In this context, the advanced study of Byzantine education, traditions of which the princes of Kiev wanted to spread in Rus', becomes more important.

Purpose. Ukrainian scholars prepared extensive research on the history of social and economic processes in Byzantium, as well as didactic literature on the history of Byzantium, where the heritage of the postmodern humanitaristics was used. However, the development of education in Byzantium has not been properly covered in the scientific literature yet.

Results. In the Byzantine sense, education has always been a requirement for accessing top public and church positions, thus it ensured social promotion of persistent representatives of the middle and lower strata.

Byzantine education was represented by different types of educational institutions, degrees and forms of study, in which there was no uniformity. The schools with one teacher were typical, in which the teacher taught one or more subjects. The personality of the teacher was the determining factor in the content and form of study, as well as the long-term functioning of the institution. Most children obtained primary education. Secondary education institutions operated in Constantinople and large cities.

The basis of educational training in Byzantium was an inseparable educational complex, which from the elementary course (reading and counting) through the middle level (grammar, rhetoric, logic, mathematics, astronomy, physics) reached the higher level, represented by philosophy and theology. The ancient classical heritage remained an important part of the curriculum.

Conclusion. Education was taken as an essential characteristic of the Byzantine, a sign of a special social and spiritual status, and even as a morality criterion. Being a Byzantine meant to become a bearer of culture and knowledge. The attitude of Byzantines to education has always been an important element of the doctrine of cultural exclusivity.

Key words: Byzantine education, didascaloses, grammar schools, rhetorical schools, educational component.

Одержано редакиією 17.10.2018

Прийнято до публікаиії 15.11.2018

\author{
УДК 343.25:340.15(37)](045) \\ DOI: 10.31651/2076-5908-2018-3-4-34-40
}

\author{
БОЛКВАДЗЕ Вахтанг Зурабович, \\ студент IV курсу HНI економіки і права \\ Черкаського національного університету \\ імені Богдана Хмельницького, \\ e-mail: vahtya1@yandex.ua
}

\section{СМЕРТНА КАРА В ОСМИСЛЕННІ ВІЗАНТІЙСЬКИЙ ЮРИСТІВ}

На основі аналізу кримінального законодавства Візантійської імперії, також коментарів до нього відомого каноніста ХІІ cm. Феодора Вальсамона визначено ставлення церкви і правників щзодо застосування смертної кари. Встановлено тенденцію до загальної гуманізачії кримінального візантійського права. Доведено, шуо позиція візантійського юриста фактично містить відмову від смертної кари як виду кримінального покарання взагалі, щуо не відповідає ні релігійним, ні теоретичним, ні практичним цілям скарання.

Ключові слова: законодавство Візантійської імперії, візантійські юристи, кримінальні покарання, смертна кара, Ф. Вальсамон.

Постановка проблеми. У сучасному світі наявні держави, які відмовилися від смертної кари, водночас є країни, де досить активно їі застосовують. Прикметно, що в обох групах держав не вщухають суперечки між противниками і прихильниками кари смертю. У дискусіях беруть участь не тільки юристи, а й політики, філософи, соціологи, економісти, письменники, представники різних конфесій тощо. Особливої значущості набуває правова політика сучасних, перш за все європейських держав, що стосується використан- 
ня смертної кари як вищої і виняткової міри покарання. В країнах Свросоюзу розгорнуто потужну кампанію щодо усунення інституту покарання смертю зі складу правових систем світу як таку, що не відповідає основним цінностям цивілізованого суспільства і порушує засадничі права людини і громадянина.

Позбавлення життя людини, яка порушила певні норми (наприклад, звичай кровопімсти), відомо задовго до виникнення держави. Разом з тим історія кримінального права цивілізованого світу, за винятком окремих періодів, свідчить про генезу щодо обмеження його застосування. До нині в спеціальній літературі усталено, що вперше проблему смертної кари було актуалізовано італійським філософом Чезаре Беккаріа в роботі «Міркування про злочини і покарання» (1764) [1]. Завдання нашого дослідження полягає у спробі віднайти паростки гуманізації страти в правових системах Середньовіччя, зокрема Візантії.

До феномену візантійського права зверталося чимало вчених, мислителів і політичних діячів, оскільки Візантійська імперія стала зразком розвитку інститутів права і державності країн Свропи та Близького Сходу. Розроблене у Візантії цілісне вчення про державу і право стало фундаментом, своєрідним еталоном для становлення української правової культури, а політико-правові інститути суспільства ромеїв після прийняття Руссю християнства зумовили рецепцію теоретичних засад і принципів функціонування. 3 огляду на це наукове узагальнення певних аспектів історії візантійського права набуває актуальності.

Аналіз останніх досліджень і публікацій. Питання становлення і розвитку інституту смертної кари в кримінальному законодавстві Російській імперії цікавили найвизначніших представників історико-правової думки. Найбільш повно проблема розроблена в кінці XIX - початку XX ст. у працях М. Д. Сергеєвського, О. Ф. Кістяківського, М. П. Загоскіна, Л. С. Бєлогриць-Котляревського, М. М. Гернета тощо [2]. Першою спеціальною вітчизняною роботою про страту стала монографія професора О. Ф. Кістяківського «Дослідження про смертну кару» (1867), що не втратила наукового значення і понині [3]. У цьому контексті дослідники звернулися до вивчення історії візантійської держави і права. Серед них зазначимо, зокрема, Д. І. Азаревича, А. П. Каждана, І. П. Медведєва, Г. Г. Літавріна, Ю. А. Кулаковського, О. Е. Липшиць, Д. М. Петрушевского, 3. В. Удальцову, Ф. І. Успенського [4-8]. Утім у сучасній українській історико-правовій думці наявні лише поодинокі звернення до цієї проблематики [9].

Мета розвідки полягає у вивченні на підставі аналізу правових пам'яток підходів до тлумачення смертної кари візантійськими юристами.

Виклад основного матеріалу. Запровадження смертної кари на світанку європейської цивілізації в систему кримінального права як одного з головних іiї інститутів мало епохальне значення. Цим касували архаїчний звичай кровопімсти з його вакханалією безперервних убивств і взаємознищення родів, усували первісний анімістичний «комплекс Еринії». 3 того часу держава перебрала обов'язок - найповніше задовольнити почуття помсти і водночас зупинити ескалацію вбивств: викупна страта відтоді стала справою держави $[10,7]$.

Утім держава швидко набралася смаку до кримінальної репресії, розповсюдивши його на широкий спектр правопорушень, часом досить незначних, а також виявила надзвичайну винахідливість у можливих способах виконання покарання. Класичним взірцем державного етапу розвитку ідеї відплати в поєднанні з метою залякування було римське кримінальне право, де poena capitis означала перш за все смертну кару в іiі страшному розмаїтті, про що оповідав у сентенціях римський юрист Павло [11]. Навіть у випадках, коли poena capitis замінювали альтернативними видами покарань, пов'язаними з втратою свободи і громадянських прав, вона означала умовну, «політичну» смертну кару. Смертна кара виходить на перший план і де-факто стає poena ordinana.

Поширення християнства суттєво не змінило ситуацію, оскільки церква, апелюючи до відомих біблійних приписів (Кн. Быт. 9, 6; Кн. Исх. 21.12-17; 22.18), а також до вчення апостола Павла, який стверджував, що влада «не просто так носить меч» (Посл. к римлян. 13.4), аж ніяк не оскаржувала законність страти. Від св. Кипріяна до Августина збереглися тексти, підкріплені соборними постановами, автори яких не сумнівалися, що світська влада не тільки може, а й повинна застосовувати право карати на смерть.

Аналізуючи позицію церкви в питанні про культивування страти, наведемо приклад 3 української історії. Оповідаючи про судову реформу Володимира Хрестителя, яка мала 
стати відповіддю держави на збільшення розбоїв, літописець у «Повісті временних літ» повідомляє: «І почастішали розбої, і сказав єпископ Володимиру: «От побільшало розбійників, чому не караєш?» Він же відповів: «Боюся гріха». Вони ж сказали йому: «Ти поставлений Богом на кару злим і на милість добрим. Тобі належить карати розбійника, але після встановлення вини» [12]. Оскільки цей випадок датується християнським періодом правління Володимира (після 988 р.), дослідники вбачали в ньому спробу грецького духовенства запровадити в Русі дію візантійського кримінального права, «прищепити до руської дійсності страту розбійників, визначену Кормчою книгою» $[2,17,23]$. Незважаючи на спроби пояснити введення в Русі смертної кари «зростанням класових протиріч», прагненням «стратами припинити розбої чи зменшити їх кількість» $[13,80]$, вважаємо, що одне не суперечить другому: грецьке духовенство могло скористатися зростанням розбійництва як приводом розповсюдження дії «візантійського закону» щодо християнізованої Русі. Чи мали єпископи на увазі конкретну норму, зафіксовану Кормчою, що передбачала за розбій повішення на дереві, як припускав професор I. П. Загоскін, достеменно не відомо. Утім варто наголосити, що в цьому випадку літописець подав позицію церкви щодо смертної кари.

Відзначимо, що у «злочинах» проти релігії церква дотримувалася подібної тактики. Щоправда, припинення гонінь на християн зумовило більш обачніше звернення до смертної кари в справах релігії, яку зарезервували тільки щодо віровідступників і манихеям, що належали до розряду crimen publicum. Водночас за бажання, а також в умовах теологічної та історичної невизначеності статусу таких «делинквентів» під ці категорії можна було підвести будь-яку єресь, що і робили протягом Середньовіччя $[4,24]$. Посилення партнерства держави і церкви Заходу в церковному судовому процесі призвело до визрівання класичної форми «аутодафе», а багаття від іскри, спричиненої «актом віри», палали протягом багатьох століть у державах германо-романського світу.

На християнському Сході церква лишалася в рамках давньохристиянської покаянної дисципліни, непоодиноко декларувала відмову від можливості «умивати руки» через передавання єретика державній юстиції. Феодор Студит, приміром, нагадуючи про те, що жоден церковний канон зроду ні для кого не передбачав покарання смертю чи навіть бичуванням, висловив фундаментальний аргумент на користь незастосування страти єретиків: адже в цьому випадку їх позбавляють будь-якої можливості покаятися - конфесійний варіант юридичної проблеми незворотності покарання смертю [8, 457]. Держава, таким чином, не могла особливо розраховувати на допомогу церкви, і мала боротися з єресями (павликіанами, богомилами) власними засобами, без необхідного ідеологічного, а почасти й юридичного обгрунтування. На думку Г.-Г. Бека, протягом середини IX - XV cт. у Візантії відбувся єдиний «єретичний процес», що підпадає під категорію «аутодафе», жертвою якого став спалений на багатті богомил Василій [14].

Щодо «цивільних» злочинів візантійське кримінальне законодавство не лишалося незмінно суворим. Дійсно, воно успадкувало від Риму весь «арсенал» кримінальних покарань, зафіксувавши їх у Дигестах і кодексі Юстиніана. Водночас розпочалася їх адаптація в аспекті подальшого обмеження та пом'якшення, як зазначено в Еклозі, «в дусі більшого людинолюбства» $\mathrm{i}$ «милосердя» [15].

Важливіше відзначити загальну «гуманізацію» кримінального візантійського права. Певним чином дивно звучить поняття «гуманізація» щодо «пенального» титулу Еклоги, прикметна риса якого - широта масштабів тілесних і пов'язаних з каліцтвом покарань (вірогідно в кримінальному праві ісаврійців відображено звичаєве право, за яким злочинця карали втратою тієї частини тіла, якою було скоєно злочин). Утім, незважаючи на варварську жорстокість, подібні покарання законодавці могли розглядати в контексті проголошених «виправлень у дусі більшого людинолюбства»: адже вони, за звичай, були заміною страти. Навіть у випадках, коли за ті чи інші правопорушення в Еклозі зберігалася смертна кара (інцест між близькими родичами, гомосексуалізм, умисний підпал, отруєння з летальним результатом, чари, вбивство, розбій), простежується тенденція відмови від особливо жорстоких способів страти (повішення, спалення і т.д.) [15]. Саме до кримінально-правової частини Еклоги (до 17-го «пенального» титулу, який становить 1/5 частину їі обсягу і 1/3 загальної кількості статей) вживано поняття «філантропії», хоча підняті в преамбулі питання належать до проблематики мети й ефективності покарань. На думку 
проф. С. Трояноса, Еклога представляє першу законодавчу пам'ятку, пенітенціарна система якої чітко і недвозначно передбачала обидві основні цілі покарання - слугувати засобом справедливого скарання за заподіяну шкоду (спокутування провини) і засобом залякування (превентивна функція покарання) [8, 478].

Незважаючи на спроби відмови від запровадженої в Еклозі системи покарань і спроби реабілітації смертної кари (щоправда з обмеженням свободи судді у виборі способу здійснення страти: виключно «смерть від меча», тобто відтинання), до яких вдавалися пізніше (в Додатках до Еклоги, в Еклогадії, в Приватній Поширеній Еклозі), цей новий дух імперського кримінального права зберігся і був результативним. Зокрема, візантійське законодавство почало забороняти тортури як такі, що суперечать інституту «філантропії», частково були еліміновані покарання смертю і в законодавстві імператорів македонської династії, приміром у Василіках Льва VI [16, 53; 5, 61]. Нині кримінальне право Ісагоги, Прохирона і Василік ще недостатньо вивчено. Разом з тим перші спроби зроблено самими візантійцями, зокрема відомим каноністом XII ст. Феодором Вальсамоном.

«Досконалий законотворець» і «світило юриспруденції» - так Ф. Вальсамон оцінений своїми сучасниками. Певною мірою звертається до напрацювань Вальсамона і сучасна наука, про що свідчать програми колоквіумів з історії канонічного права XII ст. Водночас, як зауважив I. П. Медведєв, донині поза увагою дослідників залишилося тлумачення візантійським правником Ф. Вальсамоном поняття кримінального покарання, у той час як висловлені ним ідеї знаменували якісні зрушення в питанні застосування смертної кари [8, 468].

Розглянемо запропоновані Ф. Вальсамоном підходи на прикладі його коментаря до розділу 25 Номоканона «Про кліриків-відступників, жерців, чарівників, чорнокнижників, астрологів, числогадателів, віщування, отрути й амулети». Після посилання на відповідні церковні канони (62-й апостолів, 1 і 2-й Анкірського собору, 36-й Лаодикійського собору, 73й св. Василія) Номоканон містить «текст», в якому наведено добірку цитат із стародавніх римських законів, запозичених переважно з дев'ятої книги 18-го титулу кодексу Юстиніана, що трактують питання дозволених і недозволених видів магії, а також санкцій за останні, серед яких фігурують спалення, конфіскація майна, заслання, відтинання. Знайшовши цей «пакет законів» і звіривши їх з відповідними статтями Василік (В. 60.39.22-25) [17], Вальсамон виявив розбіжності в тексті двох пам'яток. При цьому правник звернув особливу увагу на ті зміни, які доцільно було б трактувати в дусі «більшого людинолюбства».

Зокрема, заміну спалення порушників заборони віщувати за допомогою жертвоприношень покаранням «мечем» і більш суворого виду заслання для підбурювачів до цього менш суворим, Вальсамон схильний тлумачити в тому сенсі, що «стародавні закони змінилися в більш людинолюбний бік і вже не так жорстко викладені в ревізії (маються на увазі Василіки. - В. Б.), як раніше». I хоча такого роду «прогрес», на думку сучасних дослідників, виглядає досить сумнівним (Нарбеков, приміром, взагалі не бачить «великої різниці між викладом кодексу і Василік»), саме він дав привід Ф. Вальсамону запропонувати власну концепцію кримінального покарання і свою позицію в питанні про смертну кару [18, 310].

«На підставі постанов, поданих у тлумаченні цього розділу, зауважимо, якщо за Дігестами і Кодексами, які діяли до реформи, під кримінальне покарання підводили і спалення, і відтинання, і повішення, то автор оновлення царських законів і укладач Василік не прийняв цього і у викладених у Василіках постановах Кодексу не помістив цих трьох покарань». 3 огляду на це Ф. Вальсамон рекомендував не звертати уваги на вміщені в I титулі VII книги (60-а книга Василік) закони, які суть Дигести і окреслюють, що кримінальне покарання $є$ і спалення, і відтинання, і повішення [19]. Аргументує він свою позицію так: оскільки пізніші постанови (Кодекс Юстиніана), де це викладено, не прийняті, то Дигести і поготів. Ф. Вальсамон рекомендує розглянути більш пізні закони, що містяться в розділі 39 (титулі 39 книги 60 Василік), а не на Дигести, які втратили своє значення на підставі давності.

Також на підставі цього розділу Ф. Вальсамон зауважує, що як не прийняв імператор того, щоб кого-небудь піддавали спаленню, так не прийняв він усікновення і відтинання халдеїв і магів, що замінено покарання триманням у кайданах. Зазначимо, що вчений каноніст готував коментар за дорученням візантійського імператора Мануїла Комніна, за якого смертна кара взагалі не застосовувалася. За свідченням Є. Солунського, Мануїл пом'якшував присуди, що передбачали страту, замінюючи ії скаліченням. Водночас імпе- 
ратор домагався більш суворого і неухильного виконання решти покарань, зокрема для вбивць, окреслюючи неприйнятність поблажливого ставлення до них, навіть тих, які скористався правом притулку, і фактично висуваючи принцип невідворотності покарання [8, 477].

Зауваживши вищезазначене, а також те, що відтинання, спалення, отруєння, побиття камінням, скидання в прірву, є не кримінальним покаранням, а нелюдським убивством (кримінальна кара - це вигнання, осліплення, відсікання руки та інше, що дає злочинцю час для каяття шляхом видалення винного і завдяки тривалості покарання), Ф. Вальсамон констатував, що в разі певні закони Василік суперечать викладеному науковому підходу, так це Дигести, і вони не повинні мати сили. Адже узаконено, що постанови (Василік) вищі за Дигести, у разі вправнення дечого щодо одного предмета, і що за законами і всіма новелами маємо тлумачити закони в дусі більшого людинолюбства i, керуючись цим, встановлювати присуд вини.

3 огляду на вищевикладене Ф. Вальсамон не дивується, що собор у Константинополі за днів святійшого патріарха Михайла (II Куркуаса) Оксіта (1143-1146) ухвалив і доручив спалити богомилів. Оскільки про закони тоді, природно, не було й мови, тим більше що богомили, неухильно тримаючись своєї єресі, заздалегідь обирали спалення як страдництво $[18,312]$. Будучи обізнаним, що жоден церковний канон ніколи не допускав кари, а церковний закон взагалі не містить тілесних покарань, а застосовує їх закон цивільний, Ф. Вальсамон висловлював подив, яким чином собор ухвалив таке рішення. Візантійський юрист констатував, що відсікати єретиків від тіла християн навчені, а карати їх так і не навчилися; але затятих варто передавати під дію цивільного закону, і присуд має виносити світська влада.

Таким чином, аналіз фрагментів коментарів Ф. Вальсамона до розділу 25 Номоканона дає підстави констатувати досить розвинену систему уявлень у візантійських юристів про основні принципи кримінального права. По-перше, відзначимо наявність принципової відмови від ототожнення кримінального покарання, зокрема, найвищої кари, зі смертною карою, заміна останньої спектром альтернативних видів поправних кар. Тим самим задовольняли запити новітньої прогресивної криміналістики: вищу міру в «ієрархії покарань» не повинні займати над міру люті кари, оскільки важливо було зберегти співмірність між злочинами і покараннями. У разі, якщо буде вчинено особливо «небезпечний і жахливий злочин», а найвищу кару вже використано для менш тяжких злочинів [20, 62].

По-друге, позиція візантійського знавця канонів фактично містить відмову від смертної кари як виду кримінального покарання взагалі, що не відповідає ні релігійним, ні теоретичним, ні практичним цілям скарання. За традицією Ф. Вальсамон віддає належне позиції церкви в цьому питанні: він за передачу злочинців для покарання світській владі відповідно до «цивільних законів». Утім «цивільний закон» він ототожнював з Василіками, де запропоновані законодавством попередніх століть покарання смертю були частково еліміновані.

Погоджуємося з думкою професора Г.-Г. Бека, що Ф. Вальсамон вочевидь не пов'язує 3 переданням церквою єретика державі для скарання ніякого права церкви вимагати визначеного виду покарання, як на це претендували західні церковні інквізиційні суди [14, 53]. Над «певним видом покарання» візантійський юрист не мав на увазі страту, бо, окресливши іiі «нелюдським убивством, а не кримінальним покаранням», він визначив і свою позицію щодо проблеми, яку нині відома правозахисна організація «Міжнародна амністія» визначає словами: «Коли вбиває держава».

Висновки. Незважаючи на традиційну аргументацію знавця візантійського канонічного права Ф. Вальсамона проти смертної кари, продуктивною видається думка про переваги ізоляції злочинця від суспільства і «тривалість покарання», за що ратують і сучасні аболіціоністи, вважаючи, що в цьому випадку забезпечується достатня і повторювана наочність покарання. Унікальним для Середньовіччя вважаємо міркування Вальсамона про недієвість, отже неправомірність і недоцільність смертної кари, висловлені вченим з приводу справи зі спаленням богомилів.

Безсумнівно Вальсамон не розвинув своїх поглядів з цих питань, утім загальний вектор його умонастрою проглядається досить чітко. Вищевикладене дає підстави характеризувати візантійського юриста XII ст. як попередника апостола новітнього аболіціонізму 
італійського юриста XVIII ст. Чезаре Беккаріа, праця якого «Про злочини і покарання» спричинила переворот у поглядах цивілізованого людства на проблему смертної кари. Констатувати, що в 28-му розділі трактату Беккаріа («Про смертну кару») «вперше розум і почуття поєдналися в безумовному засудженні страти», на нашу думку, допускати неточність: це вже було у Візантії.

\section{Список використаної літератури}

1. Чезаре Беккариа. О преступлениях и наказаниях / пер. с итал. - К.: Ин Юре, 2014. -240 с

2. Загоскин Н. П. Очерк истории смертной казни в России / Н. П. Загоскин. - Казань: Университетская тип., 1892. -102 с.

3. Кистяковский А. Ф. Исследование о смертной казни / А. Ф. Кистяковский. - К.: Универ. тип., 1867. $281 \mathrm{c}$.

4. Азаревич Д. И. История византийского права / Д. И. Азаревич. - Ярославль: Тип. Г. В. Фалька, 1877. T. II. $-176 \mathrm{c}$.

5. Каждан А. П. Василики как исторический источник / А. П. Каждан // Византийский временник. - М.: Издательство АН СССР, 1958. - Т. 14. - С. 56-66.

6. Липшиц Е. Э. Несколько замечаний о Василиках как источнике / Е. Э. Липшиц // Византийский временник. - М.: Наука, 1958. - Т. 14. - С. 76-80.

7. Липшиц Е. Э. Законодательство и юриспруденция в Византии IX-XI вв.: историко-юридические этюды / Е. Э. Липшиц. - Л.: Наука, 1981. - 246 с.

8. Медведев И. П. Правовая культура Византийской империи / И. П. Медведев. - СПб.: Алетейя, 2001 . $576 \mathrm{c}$.

9. Омельчук В. Судові повноваження Церкви та канонічні покарання у Візантійській імперії [Електронний ресурс] / В. Омельчук. - Режим доступу: http://shron1.chtyvo.org.ua/Omelchuk_Volodymyr/ Sudovi_povnovazhennia_Tserkvy_ta_kanonichni_pokarannia_u_Vizantiiskii_imperii.pdf

10. Зелинский Ф. Идея возмездия в античной трагедии и жизни / Ф. Зелинский // Русская мысль. -1912. №. XI. - C. $1-46$.

11. Моммзен Т. История Рима [Електронний ресурс] / под ред. С. И. Ковалева, Н. А. Машкина. - СПб.; Ювента, 1997.

12. Повість врем'яних літ: Літопис (За Іпатським списком) / пер. $з$ давньоруської, В. В. Яременка. - К.: Рад. письменник, 1990. - 558 c. http://litopys.org.ua/pvlyar/yar04.htm

13. Свердлов М. Б. От Закона Русского к Русской Правде. М.: Юрид. лит-ра, 1988. - 176 с.

14. Beck H.-G. Actus Fiden Wege zum Autodafŭ. Munchen, 1987. 72 p. (In

15. Эклога: Византийский законодательный свод VIII века / пер. Е. Э. Липшиц. М.: Наука, 1965. - 228 с.

16. Ahrweiler 3. LSidŭologie politique de 1Sempire byzantin. P., 1975. P. 53. Not. 2.

17. Basilicorum Libri LX, Series A / Ed. 3. J. Scheltema, D. Holwerda, N. van der Wal. Groningen, 1988. Vol. VIII. P. 3009.

18. Нарбеков В. Номоканон Константинопольского патриарха Фотия с толкованием Вальсамона. Ч. 2: Русский перевод с предисловием и примечаниями. - Казань: Универ. тип., 1899. - разд. паг.

19. Дигести [Електронний ресурс]. - Режим доступу: http://www.thelatinlibrary.com/justinian/digest $48 . s h t m l$

20. Решетников Ф. М. Беккариа. М. Юрид. лит-ра, 1987. - 128 с.

\section{References}

1. (2014) Cesare Beccaria. About crimes and punishments. Kiev: In Yure (in Russ.)

2. Zagoskin, N. P. (1892). An outline of the history of the death penalty in Russia. Kazan: University print. (in Russ.)

3. Kistyakovskiy, A. F. (1867). The study on the death penalty. Kiev: University print. (in Russ.)

4. Azarevich, D. I. (1877). History of Byzantine Law. Yaroslavl: Type. G.V. Falka. Vol. II. (in Russ.)

5. Kazhdan, A. P. (1958). The Basilicas as a historical source. Vizantiyskiy vremennik (Byzantine Tempus). Moscow: Publishing house of the USSR Academy of Sciences, 14, 56-66. (in Russ.)

6. Lipshits, E. E. (1958). A few remarks on the Basilicas as a source. Vizantiyskiy vremennik (Byzantine Tempus). Moscow: Publishing house of the USSR Academy of Sciences, 14, 76-80. . (in Russ.)

7. Lipshits, E. E. (1981). Legislation and jurisprudence in Byzantium IX-XI centuries: historical and legal studies. Leningrad: Science. (in Russ.)

8. Medvedev, I.P. (2001). Legal culture of the Byzantine Empire. St. Petersburg: Aleteya. (in Russ.)

9. Omel'chuk, V. (2013). The judicial powers of the Church and canonical punishments in the Byzantine Empire [Electronic resource]. - Access mode: http://shron1.chtyvo.org.ua/Omelchuk_Volodymyr/ Sudovi_povnovazhennia_Tserkvy_ta_kanonichni_pokarannia_u_Vizantiiskii_imperii.pdf(in Ūkr.)

10. Zelinsky, F. (1912). The idea of retribution in the ancient tragedy and life. Russkaya mysl' (Russian thought), XI, 1-46. (in Russ.)

11. Mommsen? T. (1997). History of Rome. In S.I Kovalev, N.A Mashkin (Ed.). St. Petersburg; Juventa. (in Russ.)

12. The Tale of Bygone Years: Chronicle (On the Hapat List) (1990) [Electronic resource]. Translation from Old Russian V. V. Yaremenko. Kyiv: Soviet writer. - Access mode: http://litopys.org.ua/pvlyar/yar04.htm(in Ukr.)

13. Sverdlov, M. B. (1988). From the Law of Russian to Russian Pravda. Moscow: Legal literature. (in Russ.)

14. Beck, H.-G. (1987). Actus Fiden Wege zum Autodafŭ. Munchen. (in Germ.) 
15. Ekloga: Byzantine Legislative Code of the VIII Century (1965). Translation E. E. Lipschitz. Moscow: Science. (in Russ.)

16. Ahrweiler, 3. (1975). LSidйologie politique de 1Sempire byzantin. Paris. . (in French).

17. Basilicorum Libri LX, Series A. (1988). In 3. J. Scheltema, D. Holwerda, N. van der Wal (Ed.). Groningen, Vol. VIII. (in Latin.)

18. Narbekov, V. (1899). Nomokanon of Constantinople Patriarch Photias with the interpretation of Walsamon. Vol. 2: Russian translation with preface and notes. Kazan: University print. (in Russ.)

19. Digesty [Electronic resource]. - Access mode: http://www.thelatinlibrary.com/justinian/digest48.shtml(in Latin.)

20. Reshetnikov, F. M. (1987). Beccaria. Moscow: Legal literature. (in Russ.)

BOLKVADZE Vakhtang, the student of the Institute of Economics and Law, Bohdan Khmelnytsky National University of Cherkasy, e-mail: vahtya1@yandex.ua

DEATH PENALTY IN PERCEPTION OF BYZANTINE LAWYERS

Abstract. Introduction. Today, the legal policy of the modern, first of all European countries, regarding the use of the death penalty as a capital and exceptional punishment becomes more significant.

Purpose. It is established in the special literature that for the first time the problem of the death penalty was mainstreamed by the Italian philosopher Cesare Beccaria in his treatise "On Crimes and Punishments". The goal of the article is to find rudiments of humanization of the penalty in the legal systems of the Middle Ages, in particular, Byzantium.

Results. Comments to Section 25 of Nomocanon, proposed by Byzantine canonist of the $12^{\text {th }}$ century Theodore Balsamon, have been studied. The legal scholar paid special attention to those changes that it would be advisable to interpret as "greater philanthropy". He formulated his own concept of criminal punishment and his position regarding the death penalty.

We have to state the highly developed system of representations by Byzantine lawyers about the basic principles of the criminal law. The purpose of punishment in Byzantium was just punishment for harm and intimidation (preventive function of punishment). We note the existence of a principled refusal to identify the criminal punishment, in particular, the capital punishment, with the death penalty. The position of the canonist Balsamon actually contains the abandonment of the death penalty as a form of criminal punishment in general, which does not meet neither the religious, nor theoretical and practical goals of punishment. The Byzantine legal scholar described the death penalty as "inhumane murder, not criminal punishment".

Conclusion. We consider the thoughts of Theodore Balsamon regarding ineffectiveness, hence the unlawfulness and impracticability of the death penalty, to be unique for the Middle Ages. The opinion of the Byzantine lawyer about the advantages of isolation of the criminal from the society and the duration of punishment seems to be productive.

Key words: Byzantine Empire law, Byzantine lawyers, criminal penalties, death penalty, Th. Balsamon.

Одержано редакиією 17.10.2018

Прийнято до публікаиії 15.11.2018

\author{
УДК 903.04(450.342):069.5(477-25) «15/17» ДМИТРИСНКО Катерина Віталіївна, \\ DOI: 10.31651/2076-5908-2018-3-4-40-46 магістрантка історичного факультету \\ Київського національного університету \\ імені Тараса Шевченка \\ e-mail: katyadmitrienko006@gmail.com
}

\title{
ОСОБЛИВОСТІ ВЕНЕЦЙСЬКОГО ТЕКСТИЛЮ ХV-ХVI СТОЛІТЬ НА ПРИКЛАДІ ЗРАЗКІВ 3 НАЦІОАЛЬНОГО МУЗЕЮ МИСТЕЦТВ ІМЕНІ БОГДАНА ТА ВАРВАРИ ХАНЕНКІВ
}

У статті досліджено особливості текстильного виробництва у Венеції у XV-XVI століттях. Прослідковано умови, щцо вплинули на розквіт текстильної галузі у Венецї. Зазначено про можливості використання венеційського текстилю XV-XVI століть як джерела, важливого для глибшого розуміння та вивчення історії даного періоду. Текстильне виробництво розглядається як невід 'ємна складова історії мистецтв, в контексті чого вперие досліджуються та атрибутуються ціннні зразки венеційського текстилю XV-XVI століть з Національного музею мистецฺтв імені Богдана та Варвари Ханенеків.

Ключові слова: оксамит ,иовк, текстиль, тканина, Венеційська республіка, Музей Ханенків. 